Bartın Üniversitesi İktisadi ve İdari Bilimler Fakültesi Dergisi, 2021, Cilt 12, Sayı 23

Bartın University Journal of Faculty of Economics and Administrative Sciences, 2021, Volume 12, Issue 23

E-ISSN: 2148-2497

http://iibfdergi.bartin.edu.tr/

https://dergipark.org.tr/tr/pub/bartiniibf

Araştırma Makalesi, Gönderim Tarihi: 02.02.2021; Kabul Tarihi: 23.03.2021

\title{
Covid-19 Sonrası Türk Turizm Sektöründe Oluşabilecek Firsatlar ve Riskler
}

\author{
Doç. Dr. Ayşe DURGUN KAYGISIZ
}

Süleyman Demirel Üniversitesi, İktisadi ve İdari Bilimler Fakültesi, İktisat Bölümü

aysedurgun@sdu.edu.tr, Orcid ID: 0000000280627474

\section{$\ddot{O} \mathbf{z}$}

Covid-19 başta insan sağlığı olmak üzere insanla alakalı tüm sektörleri ekonomik, sosyal ve psikolojik açıdan etkisi altına almıştır. Pandeminin yayılımını önlemek için alınan önlemler kapsamında sınırları kapatma, seyahat yasakları, karantinalar vb. önlemlerden en çok etkilenen sektörün hizmet sektörü alt bileşiminde de turizm sektörü olduğu söylenebilir. Çünkü turizmin özü insan hareketliliğini gerektirmektedir.

Pandemi sonrası tüketici davranışlarının değişeceği bunun da turizm sektöründe arz ve talep dengelerine yansıyarak ileriki dönemlerde turizm anlayışında farklılıklara yol açması beklenmektedir. Bu çalışmada ikincil veriler kullanılarak Covid-19 sonrası olması beklenen muhtemel gelişmeler 1şı̆̆ında Türk turizminde yaşanacak firsatlar ve riskler analiz edilmiştir.

Anahtar kelimeler: Covid-19, turizm sektörü, firsatlar, riskler

JEL Sınıflandırması: L8, L83 


\title{
Opportunities and Risks That May Occur in the Turkish Tourism Sector After Covid-19
}

\begin{abstract}
Covid-19 has affected all sectors related to human beings, especially human health, economically, socially and psychologically. It can be said that the sector most affected by the measures taken to prevent the spread of the pandemic such as closing borders, travel bans, quarantines, etc.is the service sector and the tourism sector in its subcomponent Because the essence of tourism requires human mobility.

It is expected that consumer behavior will change after the pandemic and this will lead to differences in the understanding of tourism in the future by reflecting on the balance of supply and demand in the tourism sector. In this study, the opportunities and risks to be experienced in Turkish tourism were analyzed in the light of probable developments after Covid-19 by using secondary data.
\end{abstract}

Keywords: Covid-19, tourism industry, opportunities, risks

JEL Classification: L8, L83

\section{Giriş}

Aralık 2019'un son haftalarında görülen coronavirüs salgını ilk olarak Çin'in Wuhan Bölgesinde ortaya çıkmış, kısa bir zaman zarfında bütün dünyaya yayılmıştır (WHO, 2020). Ortaya çıktığı ilk zamanlarda coronavirüs olarak bilinen bu virüs 12 Şubat 2020 itibariyle Covid-19 olarak adlandırılmıştır (T.C. Sağlık Bakanlığı, Covid-19 Rehberi, 2020: 5). Daha önceki küresel salgınlardan çok daha hızlı yayılarak neredeyse tüm dünyayı etkisi altına almıştır. 11 Mart 2020 tarihi itibariyle Covid-19 DSÖ tarafından pandemi (küresel salgın) olarak ilan edilmiştir. Virüsün yayılımını engelleyebilmek için seyahat kısıtlamaları, vize iptalleri, sınırların kapatılması, sokağa çıkma yasakları ve sosyal mesafe kuralları gibi önlemler alınmıştır. Alınan tüm tedbirlere rağmen neredeyse tüm dünya ve bütün sektörler Covit-19 salgınından olumsuz yönde etkilenmiştir. Covid-19 salgınından olumsuz etkilenen sektörlere finansal yardım, vergi erteleme, kredi ve danışmanlık desteği verilerek faaliyetlerine devam etmesi için desteklenmiştir (Hale ve diğ., 2020. s.3).

$\mathrm{Bu}$ süreçten kârlı çıkan, krizi firsata çeviren sektörler de olmuştur. Salgının önlenmesinde temizlik ve hijyen koşullarının ön plana çıkması bu sektörlerdeki iş sahalarının arz ve talebinin artmasına neden olmuştur. Dünya Sağlık Örgütü ve Dünya Turizm Örgütü'ne ait resmi internet sayfasında yayınlanan raporlar ve bilimsel çalışmalar incelendiğinde; hastalığın meydana geldiği günden bu yana dünya çapında koruyucu maske, eldiven, dezenfektan vb. sağlık gereçlerine talebin arttığ artışıyla ilişkili olarak sağlık gereçlerinin fiyatlarında hatırı sayılır artışların olduğu tespit edilmiştir (Mahase, 2020: 1). Bunun yanında dijital teknoloji ve bilgi iletişim 
teknolojisi endüstrileri de kazançlı çıkan sektörler arasında yer almıştır. Aynı zamanda internet üzerinden alışveriş imkânı sunan işletmeler, paket servisi yapan yiyecek içecek işletmeleri ile kargo ve benzeri lojistik işletmeler için yeni firsatlar oluşmuştur (Atay, 2020).

Günümüzde aşı çalışmaları ve aşılama işlemi farklı ülkeler tarafından yapılmaktadır. Fakat aşıların etkileri ve kalıcı bir çözüm olup olmayacağı tartışmaları devam etmektedir. Ocak 2021 itibariyle Dünya çapında Covid-19 sebepli toplam hasta rakamı; 99.2 milyon, toplam vefat rakamı ise 2.13 milyon olarak kayda geçmiştir. Türkiye'de ise 2021 Ocak ayı itibariyle toplam hasta vaka sayısı 2.429.605, vefat eden kişi sayısı ise 25073 olmuştur.

\section{Pandemi Sürecinde Türkiye}

Dünya Sağlık Örgütünce salgının yayılımının önüne geçilmesi, durdurulması ve kontrol altına alınabilmesi için ülkelere önemli vazifeler yüklenmiştir. Bu kapsamda ülkeler ekonomilerini etkileyecek ciddi tedbirler almak durumunda kalmışlardır (Acar, 2020: 14-15). Bunlar:

- Fazlalaştırılan sınır emniyetleri ve ülkelere giriş çıkış kısıtlamaları

- Hastalığın belirlendiği yerlerde zorunlu yasakların getirilmesi

- Hastalığın bulaşıcılığını azaltabilmek amacıyla toplumsal mekanlarda uygulanan dezenfekte çalışmaları

- Sokağa çıkma kısıtlamaları

- Yolculukların yasaklamaları

- Eğitim faaliyetlerine ara verilmesi,

- Dünya çapında çok sayıda katılımcılarla gerçekleştirilen festival, konser, kongre, fuarlar vb. kültürel ve sanatsal organizasyonların askıya alınması.

- Havayolu uçuşlarının ertelenmesi

- Milli ve milletlerarası düzeyde spor ve sanat faaliyetleri ve müsabakalarına ara verilmesi olarak siralanabilir.

Küresel çapta alınan önlem ve tedbirlere Türkiye de uyum sağlamıştır. Hızlı bir şekilde pandemi hastaneleri oluşturulmuş, sağlık araç-gereç ve ekipmanları üretilmeye başlanmıştır. Türkiye'de ilk etapta şubat ayı içerisinde bazı ülkelerden yolcu taşımacılığına yasaklar getirilmiştir. 10 Mart'ta ilk pozitif vakanın görülmesinin ardından yurt dışından gelen kişilere karantina uygulamaları, eğitime ara verilmesi, konser, tiyatro, sinema, düğün, eğlence merkezleri, oyun alanları vb. birçok yerin faaliyetlerinin durdurulması, bazı ülkelere uçuş yasaklarının getirilmesi, sınavların ve oyun müsabakalarının ertelenmesi, halka açık yerlerde maske takma zorunluluğu, 65 yaş üstü ve kronik hastalığı olanlara sokağa çıkma yasağı ile başlayan tedbirler artarak devam etmiştir. 1 Haziran itibari ile yasakların bazıları kaldırılmış ve yeni normal döneme geçilmiştir. Yaz ayları boyunca esnetilen tedbirler vaka sayılarındaki artış 
nedeniyle Kasım ayı itibariyle yeni yasaklar ve sınırlandırmalarla tekrardan uygulamaya koyulmuştur. Hafta içi ve hafta sonu sokağa çıkma yasakları, eğitimin tamamen online olarak yapılması, kafe, pastane, restoran vb. yeme içme yerlerinin paket servis şeklinde çalışması, kademeli ve esnek çalışma saatleri, AVM, berber, kuaför, market vb. yerlerin 10:00-20:00 saatleri arasında açık olması, sinema, internet kafe, oyun alanları, çay bahçesi vb. yerlerin faaliyetlerinin durdurulması tedbirleri 2021 Şubat ayı itibariyle halen devam etmektedir. Tüm bu yasaklar dâhilinde çevrimiçi iletişim, e-ticaret vb. dijital çözümlerle günlük hayatın temel gereksinimleri hiçbir aksaklık olmadan karşılanmaya çalışılmaktadır.

Türkiye 1 Haziran 2020 tarihinden itibaren sınır kapılarını açmış, uçuşlar serbest bırakılmış ve yabancı ziyaretçi kabulüne başlamıştır. 2019 yılında ilk 11 aylık dönemde Türkiye'yi ziyaret eden yabancı ziyaretçi sayısı 42,9 milyon iken 2020 yılının ilk 11 aylık döneminde bu sayı \%72 oranında azalarak 12 milyon kişiye gerilemiştir. Bu rakama yurt dışında yaşayan vatandaşlarımızı da eklediğimizde 2020'nin ilk 11 ayında toplam ziyaretçi sayısı 14486632 kişi olmuştur (Kültür ve Turizm Bakanlığı, 2020). Türkiye'nin, 2020 yılının ilk 11 ayında en çok ziyaretçi aldığı ülkeler sırasıyla; Rusya, Bulgaristan, Almanya, Ukrayna, İngiltere, Gürcistan İran, Irak ve Fransa olmuştur. (TURSAB, Kasım 2020). \%70 oranındaki bu azalmanın 2021 yılının yazında da devam edip etmeyeceği aşı çalışmalarının ve aşılamanın başarısına ve Covid-19 virüsünün gidişatına bağlı olarak değişim gösterecektir.

\section{Literatür}

Salgının bir senedir etkisini gösteriyor olması çalışmanın güncelliği açısından araştırmacılar arasında merak uyandırmaktadır. $\mathrm{Bu}$ nedenle hem ulusal hem de uluslararası çalışmalar hızla yapılmaktadır. Buna rağmen salgının halen devam ediyor olması etkilerinin tam olarak neler olduğu ve nasıl sonuçlanacağı konusunda çalışmaları yetersiz kılmaktadır. Fakat krizin yönetilebilmesi ve hızlı önlemler alınması açısından yapılan her çalışmanın literatüre katkı sağlayacağı düşünülmektedir. Çalışmanın bu bölümünde salgın ve turizmle ilgili olarak seçilmiş bazı çalışmalara yer verilmiştir.

Çakır ve Barakazı (2020) Covid-19'un turizm sektörüne etkisini ve alınan önlemlerin neler olduğuna dair bir çalışma yapmışlardır. Çalışmalarında, ileriki dönemlerde salgına yönelik endişelerin devam edeceğini, ekonomik ve finansal desteklere rağmen turizm sektörünün normale dönme ihtimalinin zaman alacağını belirtmişlerdir. Özaltın Türker (2020) Covid-19'un turizm sektörü üzerindeki etkisini turizm alanındaki akademisyenlerin bakış açısı ile değerlendirmiştir. Yaptığı anket çalışmasının neticesinde salgın süresince turizm talebinin düşeceğini fakat salgın sonrası yasaklar bittiğinde talepteki artışın devam edeceğini belirtmektedir. Aynı zamanda salgının iç turizmde hareketlilik yaratacağını, bireysel turizm faaliyetlerinin artacağını ve turistik mekanlarda hijyen kurallarının ön plana çıkacağını belirtmiştir. Akademisyenlerin bakış açısından değerlendirilen bir başka çalışma Kiper ve diğ. (2020) tarafından yapılmıştır. Turizm sektörünün normalleşme süreci ile birlikte 
insanların çok hızlı bir şekilde turizm faaliyetlerine katılımının gerçekleşeceğini belirtmişlerdir. Sektörde yaşanan kayıpların telafisi için ise turizm plan ve politikalarının, pazarlama faaliyetlerinin, medikal tedbirlerin kalıcı hale getirilmesinin gerekliliğinden bahsetmişlerdir. Akyol (2020) Covid-19'un sektöre etkisini turizm öğrencileri gözünden değerlendirmiştir. Akademisyenlerin bakış açılarıyla benzerlik gösteren sonuçlar elde etmiştir. Bu sonuçlar bireysel hareketlenmenin artacağı, tenha destinasyonların tercih edileceği, sağlık konusundaki denetimlerin artacağı ve bu süreçte sağlık hizmetlerinin daha iyi yönetilmesinden dolayı Türkiye’ye olan turizm talebinin artacağıdır.

Oran (2020), Covit-19 pandemisinden en fazla etkilenen sektörlerden birisinin turizm olduğunu belirtmiştir. Sektördeki işletmelerin çalışma modellerini yeniden yapılandırması ve turizm yatırımlarının teşvik edilmesi gerekliliğinden bahsetmiştir. Işık Erol (2020) turizm sektöründe pandemi kaynaklı işsizliklerin artacağını belirtmiştir. Düzgün ve Kurt (2020) salgının etkisini turist rehberleri açısından ele almışlardır. Rehberlerin kalabalık turlarla iş yaptığını ve riskli duruma düştüklerini ayrıca turizm faaliyetlerindeki durma nedeniyle tek işleri rehberlik olanların hem ekonomik hem de psikolojik sıkıntıda olduklarını belirtmiştir. İbiş (2020) Covid-19'un etkisini seyahat acenteleri açısından değerlendirmiştir. Pandemi döneminde seyahat acentelerinin de işlerini yapamaz duruma gediklerini dolayısıyla, vergi indirimi, kredi desteği, sabit giderlerin ve banka borçlarının ertelenmesi ve maliyetlerin düşürülmesi gibi desteklere ihtiyaçları olduğunu belirtmiştir.

Yenişehirlioğlu ve Salha (2020), Covid-19'un Türk turizminde tüketici davranışlarını ne yönde etkileceğini araştırmıştır. Her yıl düzenli tatil yapan 50 aileye mülakat yöntemi ile yaptıkları çalışmalarında, çoğu ailenin tatil planını ertelediği, yapacak olanların ise kendilerine ait yazlık, yayla evi ya da bungalov tarzı sosyal mesafeyi kendilerinin ayarlayabileceği yerleri tercih edecekleri sonucuna ulaşmışlardır. Özçoban (2020), Covid-19 sonrası toplumdan izole fiziki mekânların turizm faaliyeti açısından daha fazla önem kazanacağını, tam bu noktada da kırsal turizm potansiyelinin Türkiye için bir rekabet unsuru olduğundan bahsetmiştir. Ayrıca Türkiye'nin bu avantajını kullanabilmesi için kırsal turizm mekânlarının yeni arz talep doğrultusunda hizmet standartlarını güncellemesi ve kamu otoriteleri tarafindan bu merkezlere yönelik teşvik ve tanıtım kampanyalarının yapılması gerekliliğini ele almıştır. Özdemir Altınay (2020) turizm işletmelerinin gelecek tahminlerinden hem de potansiyel turistlerin görüşlerinden yararlanarak Covid-19 salgınının Türkiye'nin turizm sektöründe oluşturacağı değişimleri muhtemel senaryolar ile açıklamaya çalışmıştır. Salgın sonrası öncelikli olarak iç turizm faaliyetlerinin artacağını, doğa tabanlı turizme (dağ, yayla, tarım ve kırsal turizm) doğru bir artışın olacağını, konaklama işletmelerinin yatay büyümeye doğru bir eğilim göstereceğini ifade etmektedir. Potansiyel turistlerin görüşlerinden yola çıkan bir diğer çalışma Kabadayı ve Kardeş’e (2020) aittir. 731 kişiye yaptıkları anket sonucunda; turistlerin tercih ettikleri turizm türlerinin ve seyahat eğilimlerinin değişerek, açık alan ve doğa faaliyetlerine yöneldiklerini, turistlerin 
hijyen duyarlılığının büyük oranda arttığını ve sektörde teknolojinin önem kazandığını ortaya koymuşlardır. Bunun yanı sıra salgının turizmi dört mevsime yaymak için bir firsat olabileceğinden bahsetmişlerdir.

Yazıcı Ayyıldız (2020) Kuşadası'ndaki beş yıldızlı otellerle yaptığı görüşmelerden elde ettiği veriler 1şığında çalışmasını tamamlamıştır. Covid-19 sonrası otellerde temassız işlemlerin ve dijitalleşmenin artacağı, yasaklardan dolayı gelemeyen yabancı turistler yerine iç pazara yöneleceğini ve kişiye özel hizmet sunan daha küçük işletmelerin ön planda olduğu yeni turizm biçimlerinin artacağını belirtmiştir. Bu değişime ayak uydurmak isteyen otellerin içinde mutfak olan süit daireler ya da otel alanı içinde kiralanabilecek villalar gibi alternatiflere yönelmeleri gerektiğinden bahsetmiştir. Otel yöneticilerinin görüşleri doğrultusunda hazırlanan başka bir çalışma Karadeniz ve diğ'ne (2020) aittir. Çalışma da salgınla birlikte sağlık ve güvenlik kaygılarının artarak turizm talebini azaltacağını, dolayısıyla sektörde büyük miktarda gelir ve istihdam kaybının yaşanacağını belirtmişlerdir. Aynı zamanda hizmet ve ürün standartlarının yeniden şekilleneceği ifade edilmiştir.

Covid-19'un turizm sektörüne etkilerini araştıran bir diğer çalışma ise Alaeddinoğlu ve Rol'e (2020) aittir. Çalışma, sektörün pandemiden önemli derecede etkilendiğini fakat yeniden yapılanma açısından bir firsat olabileceğini belirtmektedir. Yapay zeka ve robotik teknolojilerin turizmin devamlılığını sağlamak adına sektörün her alanına entegre edilmesi gerekliliğinden bahsetmiştir. Aynı zamanda bakanlıklar tarafından geliştirilen güvenli turizm sertifikasyonun işletmeler tarafından alınmasını ve denetiminin yapılmasını güvenlik açısından önemli bulmaktadır.

Gössling vd. (2021) milliyetçilik, iç turizmin toparlanmadaki rolü ve daha dayanıklı destinasyonlara uzun vadeli dönüşüm, iş seyahatleri ve video konferansın yaygın olarak benimsenmesi dahil olmak üzere kısa ve uzun vadede turistlerin davranışsal talep tepkilerinin değişeceğini belirtmişlerdir. Ayrıca azalan talep nedeniyle havayollarının verimsizliğinin ve karbon salınımının aşamalı olarak azalacağını düşünmektedirler.

Skare vd (2021) 185 ülkede 1995-2019 yılları arasındaki verileri kullanarak panel veri analizi yapmışlardır. Dünya çapında pandeminin etkilerini araştırdıkları çalışmalarında, turizm endüstrisinin toparlanmasının beklenen 10 aylık ortalama toparlanma süresinden daha fazla zaman alacağını ileri sürmektedirler. Kapasite geliştirmeyi sağlamak için özel ve kamu politikası desteği önerisinde bulunmaktadırlar. Ayrıca seyahat ve turizm endüstrisinin GSYİH'ye katkısının - 4,1 trilyon dolardan 12,8 'e düşeceğini, istihdam katkısının -164.506 milyon'dan - 514.080 milyona azalacağını öngörmektedirler.

Desbiolles (2020), Covid-19'u, turizmin geleceğini daha iyi bir yola doğru yeniden düşünmek ve sıfırlamak için iyi bir firsat olarak görmektedir. Ancak turizme yönelik 'sorumlu' yaklaşımlar, tek başına böyle bir sıfırlamayı mümkün kılmadığını 
bunun yerine, böyle bir vizyon, turizmi yerel toplulukların ve yerel halkların haklarına ve çıkarlarına göre yeniden tanımlayan ve yeniden yönlendiren toplum merkezli bir turizm çerçevesini gerektirdiğini söylemektedir.

Abu Bakar ve Rosbi’ye (2020) göre pandemi turizm sektöründe arz ve talep dengesin bozulmasına yol açacaktır. Azalan talep nedeniyle turistik fiyatların düşmesine sebebiyet verecek buda eğer müdahale edilmezse turizm sektörünün çöküşüne neden olabilecektir.

\section{Covid-19 Sonrası Turizm Sektöründeki Değişimler}

Turizm faaliyetleri gezmek, eğlenmek, dinlenmek ve bazen de spor, kültür, din vb. amaçlarla seyahat etmek olarak tanımlanmaktadır (Öztaş ve Karabulut, 2006: 17) Tanımı gereği bakıldığında Covid-19'dan en çok etkilenecek sektörlerin başında turizm sektörü gelmektedir. Ayrıca turizm faaliyetleri seyahat, konaklama, yeme -içme ve ulaştırma hizmetleri başta olmak üzere yaklaşık olarak 54 ayrı sektörlerle doğrudan, 185 sektörle de dolaylı ilişki içerisindedir (Bahar ve Çelik İlal, 2020: 126). Birçok sektörle girdi çıktı ilişkisi içerisinde olması, turizm sektöründe ortaya çıkan bir sorunun diğer sektörleri de etkilemesine neden olmaktadır.

Turizm sektörü esnek talepli yapısı gereği her türlü iyi ve kötü durumdan çok çabuk etkilenmektedir. Salgınlar, terör saldırıları, doğal afetler, ekonomik ve politik istikrarsızlıklar ve siyasi olaylar vb. krizlerde turizm talebi değişiklik göstermektedir. Çünkü bireyler öncelikle fiziksel ve güvenlik ihtiyaçlarını karşılamaya yönelmekte ve turizm talebini ertelemekte veya yön değiştirmektedir (Tse, 2006: 30).

Salgın hastalıkların çok basit ve bir o kadarda hızlı şekilde insanlara bulaşması ve bir mekândan diğer bir mekâna etki edip yayılma riski nedeniyle turizm faaliyetinin temel mantığına ters düşmektedir. Çünkü turizm faaliyetlerindeki artış virüsün hızlı bir şekilde yayılmasına sebebiyet verebilir. Ayrıca hastalanma riski altında olduğunu düşünen bireyler turizm faaliyetlerini ertelemekte ya da salgın riskinin olmadığ 1 bölgelere gelmektedirler. $\mathrm{Bu}$ durumda salgınlar ve turizm arasında karşılıklı etkileşimden söz edilebilir (Kiper ve dĭg, 2020: 529).

Salgın hastalıkların turizm faaliyetlerini yakından etkilemesinden dolayı turizm talebine negatif yönde tesir etmekte ve ekonomik olarak zarar vermektedir. Verdiği zararlar kısa dönemli ve geçici veya kalıcı olup değişiklik gösterebilmektedir (EugenioMartin ve Campos-Soria, 2014: 55). Ayrıca doğal afet veya geçici krizlerin aksine salgının bitiş tarihinin belirsiz olması nedeniyle gelecek kaygılarını arttırmakta ve geniş çapta işsizlik, ekonomik daralma ve sosyolojik problemlere yol açabilmektedir (Torales vd., 2020).

Daha önceden yaşanılan salgın krizlerinin turizm faaliyetlerine olan etkilerine bakıldığında; 2001 yılında Birleşik Krallık’ta görülen ŞAP salgını başta kırsal turizme 
tesir etmiştir. Asya'da 2003 yılında ortaya çıkan SARS salgını Asya ülkeleri turizm faaliyetlerini negatif yönde etkilemiş ve ciddi ekonomik problemler ortaya çıkarmıştır (Korkut vd., 2020:73). SARS salgınından sonra uluslararası turizm gelirleri -\%1.4 oranında azalmıştır (Oran, 2020: 817). SARS salgınının Kamboçya turizm talebine olan etkilerinin geçici olduğu, salgın sonrasında talebin normal bir şekilde devam ettiği bilinmektedir (Tang ve Wong, 2009). ABD ve Meksika'da 2009'da ortaya çıkan Domuz gribi (H1N1) salgını yöresel turizmde az da olsa olumsuz etkiler yaşatmıştır (Küçükaltan, ve diğ., 2015). Genel olarak değerlendirildiğinde kriz süreçlerinde kısa vadeli durağanlık veya turizm gelirlerinde azalma meydana gelmiştir (Papatheodorou ve diğ., 2010: 39). Fakat hiçbir kriz döneminde (2008 ekonomik krizi, Irak Savaşı, SARS virüsü vb.) Covid-19 salgını kadar turist varışlarında sert düşüşlerin yaşanmadığ 1 anlaşılmaktadır (Dwyer ve diğ., 2006). Bunun nedeni Covid-19'un hızlı ve geniş alanlara yayılması, bulaş sürecinin ve tedavisinin belirsizliğini koruması yanında, zorunlu seyahat tedbirleri nedeni ile turizmi doğrudan ve aniden etkilemesidir (Çetin ve Göktepe, 2020: 90). Turizm faaliyetleri Covid-19 salgını nedeniyle 2020 yılında çok büyük oranda düşüş göstermiş ve dünya genelinde durma noktasına gelmiştir (Zheang vd., 2020: 338). Turizm faaliyetlerindeki bu azalış en çok seyahat acenteleri, tur operatörleri ve havayolu şirketlerini negatif yönde etkilemiş ve finansman krizine sokmuştur (Korkut ve diğ, 2020: 81).

Yukarıdaki bilgiler ışığında değerlendirildiğinde turizm sektörünün Covid19'dan iki farklı yolla etkileneceğini söyleyebiliriz. Bunlardan ilki seyahat sınırlaması ve karantinalar nedeniyle turizm faaliyetlerinin yapılamaması, ikincisi ise ekonomik açıdan müşkül duruma düşen bireylerin turizm faaliyetine katılamamasıdır. Her iki sebebinde turizm talebini düşüreceği aşikârdır. Salgınların turizm talebi için oldukça mühim olduğu ve salgınların meydana geldiği zamanlarda talebin ve gelirin geçici olarak azalacağı öngörülmektedir. Talepte ve gelirdeki bu mecburi azalma sonrası daralan turizm sektörü, gerekli önlemler alınması ve kriz yönetiminin başarıyla yürütülmesi neticesinde pandemi sonrası tekrardan canlanabilecektir. Nitekim yapılan çalışmalar salgının getirdiği stres sonrası insanların yeniden ve yüksek motivasyonla turizm faaliyetlerine katılacağı yönündedir (Kiper vd., 2020: 546). İkinci dünya savaş1 sonrası kitle turizmin ortaya çıkması, 2004 SARS salgınından sonra rekreasyon faaliyetlerine katılımın artması bu savı desteklemektedir. Lakin dünyadaki bölgeler ve ülkelerde uluslararası turizm faaliyetlerinin düzelme eğilimine geçmelerinin farklı düzeylerde olacağı tahmin edilmektedir. Çünkü Covit-19 sürecinde vaka sayılarının fazla olduğu gelişmiş ülkelerin bu durumla baş edememeleri, tedavide yetersiz kalmaları o ülkelere olan güveni sarsmıştır. Bu nedenle virüsün etkilerinin daha az görüldüğü gelişmekte olan bölgelerde turizm sektörünün normalleşme sürecine daha kısa sürede gireceği öngörülmektedir (Oran, 2020: 815).

Covid-19 salgını bireylerin tüketici davranışlarını etkilemiştir. Bu durumun turistik tüketici davranışlarına da yansıyacağı ve ileriki dönemlerde turizm anlayışında farklılıklara yol açacağı beklenmektedir. Salgının turizm üzerindeki etkileri iyi 
gözlemlenebilir ve yeni normale adapte olunabilirse Covid-19 krizinin sunduğu bazı firsatlar da değerlendirilebilir. Çünkü pandemi sonrası seyahat davranışlarında değişiklikler beklenmektedir. Bu değişiklikler; kişisel ekonomik refah ve harcanabilir gelir, maliyet değişiklikleri, algılanan sağlık riskleri ve pandemik kısıtlamaların bir sonucu olarak değişen tüketim kapasitelerini içeren bir dizi faktörden etkilenmektedir (Lee ve Chen, 2011; Gössling vd. 2020:14). Kitle turizminden bireysel turizme yönelme, kalabalık ortamlardan güvenli ve hijyenik özelliklere sahip daha tenha ortamlara doğru yöneliş ve geleneksel turizm anlayışından alternatif turizm imkânlarına doğru talebin artması pandemi sonrası sektörde beklenen değişimlerdir. Kitle turizminin aktif olduğu her şey dahil konseptli konaklama işletmelerinin bu durumla baş edebilmesi için sistemlerinde bazı değişiklikler/yenilikler yapmaları gerekmektedir (Özdemir Altınay, 2020: 225-227). Ayyıldız Yazıcı'nin (2020: 3352) çalışmasında böyle bir durumla rekabet edebilmek için otellerin, günlük ve haftalık olarak kiralanabilecek, içinde mutfağı olan süit dairelerin ya da otel içi villaların yeni satış ve pazarlama stratejilerinin içerisinde yer aldığını belirtmişlerdir. Ayrıca turistlerin sağlık ve güven riski destinasyon algısını değiștirmektedir. Bu nedenle, Covid-19 salgını sonrasında turistlerin altyapısı ve yüksek kaliteli tıbbi tesisleri olan destinasyonlara yönelmeleri beklenmektedir (Wen ve diğ., 2020).

Pandemi sonrası turizm arz ve talebinde yaşanacak değişimleri Türkiye turizmi açısından ele aldığımızda getireceği risklerin yanında sunacağı bazı firsatlar olduğu da görülmektedir.

\section{Muhtemel firsatlar:}

1. Covid-19 süresince bireylerin daha kısa mesafeli yerleri tercih edeceği, bu nedenle Türkiye'nin Avrupa pazarına yakınlığının bir avantaj olacağı düşünülmektedir.

2. Türkiye'de uzun süredir yapılmaya çalışılan, turizmi dört mevsime yaymak, yaz mevsimindeki yoğunluğu azaltmak ve turizm faaliyetlerini çeşitlendirmek gibi çalışmaların virüs nedeniyle zorunlu olarak bu yönde gerçekleşmesi beklenmektedir.

3. Türkiye'nin birçok ülkeye nazaran virüsle mücadelede başarılı olması Türkiye'nin sağlık sektörüne olan güveni arttırmıştır. Bunun bir getirisi olarak sağlık turizmine olan talebin artacağı söylenebilir. Çınar ve Özkaya (2020: 40-41) Türkiye'nin coğrafi konumu, dünyanın en büyük 7. Jeotermal kaynaklara sahip olması, turizm hizmetini sağlık hizmeti ile birleştirebiliyor olması, fiyatların benzer ülkelere göre daha uygun olması Türkiye'yi medikal turizm alanında avantajlı konuma getireceğini söylemektedir. Bahar ve Çelik İlal (2020: 133), Türkiye'nin kaliteli ve ucuz sağlık hizmeti konusunda önemli bir arza sahip olduğunu ve sağlik turizmi bu süreçte iyi değerlendirilirse, hastaneleri, çalışanları, yatakları, turistik tesisleri dinamik 
hale getirerek, kadrolarını güçlendirerek, sadece sağlık turizminden 45-50 bin dolar gelir edebileceğini öngörmektedir.

4. Kalabalık ortamlardan kaçış ve sosyal mesafe duyarlılığı nedeniyle bireysel olarak yapılabilecek etkinliklerde artış beklenmektedir. Kitle turizm faaliyetlerinin çok fazla olduğu ülkemizde ilk etapta negatif bir durum gibi görünse de uzun vadede avantaja dönüşmesi beklenmektedir.

5. Geleneksel turizm anlayışından alternatif turizm türlerine (sağlık, kültür, spor, doğa, eko, kırsal, kış ve dağ, kongre, inanç, yayla, gastronomi turizmi) doğru talep artışı beklenmektedir.

6. Turistik tüketicilerin kitlesellikten uzak durma gayreti ve daha bireysel butik tatillere eğilimlerinin artacağı öngörülmektedir. Bu durumun turistin ortalama harcamasını arttırarak turizm gelirini arttırıcı etkisi olabilir.

7. Her şey dahil paket tur sistemlerinin sosyal mesafeyi koruma riskinden dolay1 fazla tercih edilmeyeceği böylelikle her şey dahil paket tur sisteminin turizm sektöründe ortaya çıkardığı ucuza konaklama, otel dışı hiçbir harcamanın yapılmaması gibi nedenlerle oluşan düşük turizm gelirinin (Kalkınma Bakanlığı, 2018: 47) uzun vadede ortadan kalkacağı öngörülebilir.

8. Sektörde arz fazlası nedeni ile ortalamanın altında gerçekleştiği düşünülen turist başına düşen gelir 600-850 USD aralığın da bulunmaktadır. Nicelik yerine nitelik hedeflerine yönelerek, hacim ile kalite arasındaki dengenin tekrar düzenlenmesi için yaşanılan bu süreç firsat olarak görülmektedir (Çetin ve Göktepe, 2020: 94).

9. Kalabalıklardan uzak durma isteği daha az insanın olduğu kırsal yerlere olan talebi arttırması beklenilmektedir (Arslan ve Kendir, 2020: 3673). Page ve Getz'e (1997: 13) göre kırsal turizme katılan turistlerin; eğitim ve gelir seviyeleri yüksek, çevreye duyarlı ve tatil harcamaları kitle turizmi harcamalarına göre daha fazla olmaktadır. Yüzölçümünün \%67'si kırsal alandan oluşan Türkiye için bu durum rekabet üstünlüğü sağlamaktadır. Ayrıca turizm talebinin yoğun olarak gerçekleştiği Ege ve Güney sahillerinin aynı zamanda kırsal alanlara da sahip olması büyük bir avantaj olarak görülebilir (Özçoban, 2020:863).

10. Ulusal turizmdeki hareketlenmenin uluslararası turizme göre daha hızlı olacağı öngörülmektedir (Bora, 2020:812). Yasakların esnetilmesi akabinde ilk olarak iç turizm hareketliliğinde bir artış beklenmektedir. Özellikle gelirleri ekonomik duruma göre karşılaştırmalı olarak sabit kalan kamu görevlileri ve emeklilerin, güvenli bir ortam sağlanması durumunda hızla tatil talebinde bulunacakları düşünülmektedir (Çetin ve Göktepe, 2020: 93).

11. Kamp, karavan, mevsimlik konut kiralama, yat kiralama gibi normal süreçlerde çok fazla tercih edilmeyen tatil türlerine salgın döneminde ilginin artacağı düşünülmektedir.

12. Salgının; insanların sağlık ve çevre konusunda daha hassas olmasına, duyarlı turizm uygulamalarının daha fazla rağbet görmesine, sorumlu ve 
sürdürülebilir turizm (Gössling, 2020) felsefesinin kıymetinin anlaşılmasına yol açacağı beklenmektedir.

13. Bundan sonraki süreçte turistler konaklama tercihlerinde hijyen ve güvene önem verecekleri için, konaklama sektöründe bu alanda yeni adımlar atılmasını ve standartların yükseltilmesini gerekli kılacaktır.

14. Pandemi sektörde online işlemler, dijitalleşme, robot ve otomasyonun önemini arttırmıştır. $\mathrm{Bu}$ vb. durumlar 4.0 endüstri çağına uyumu hızlandırabilir.

\section{Oluşabilecek riskler:}

1. Home ofis çalışma şeklinin pandemi sürecinde devam etmesinin iş amaçlı seyahatleri azaltacağı beklenmektedir.

2. Uzaktan eğitim, video konferans vb. etkinliklerin bu süreçte yoğun olarak kullanılması kongre, konferans ve sempozyum gibi etkinliklerin yapılması için fiziksel ortam şartını gereksizleştirmiştir. Bu durum kongre turizmini olumsuz yönde etkileyecektir.

3. Uzun süre kapalı kalan turistik işletmelerde çalışanların ekonomik açıdan zor durumda kalacağı ve mecburen gelir elde etmek için başka sektörlere kayacakları beklenmektedir. $\mathrm{Bu}$ nedenle sektörde yetişmiş eleman kaybı oluşacağı öngörülmektedir (Özaltın Türker, 2020: 220)

4. Yukarıdaki neden dolayısıyla müşteri memnuniyetsizliğinin ortaya çıkması beklenmektedir (Özaltın Türker, 2020: 220)

5. Sektörde gelişecek teknolojik trendler ve değişimlerin (otomatik kapılar, temassız ödeme, önceden menü rezervasyonları, açık büfenin sonlanması) teknolojik ve yapısal işsizliği artırması beklenebilir (Özcan ve Kar, 2020: 596).

6. Virüsün orta yaş ve üçüncü yaş turizmini belli bir dönem sekteye uğratması beklenmektedir.

7. Mesafe, hijyen ve sanitasyon kurallarına uyma aşamasında kar marjları düşen işletmelerin bu açığı kapatmak için fiyatlarını arttırması nedeniyle yüksek maliyetli tatil anlayışının ortaya çıkması muhtemeldir.

8. Sosyal toplulukları kendi sahip olduğu belirli etnik grup veya kültüre göre özellikle dil, yaşayış, adet ve dine göre değerlendirip, milliyetçi duyguları harekete geçirme ihtimali turizmi negatif yönde etkileyebilir (Aydın ve Doğan, 2020: 106-108).

9. Türkiye turizminin ana pazarını oluşturan Avrupa ülkelerinin salgından çok fazla etkilenmiş olması (Çetin ve Göktepe, 2020: 93) yabancı turist sayısındaki artışın uzun vadeye yayılmasına neden olabilir.

10. Turizm gelirinde azalmanın bir müddet daha devam etmesi beklenmektedir.

11. Turizm yatırımlarında durgunluk oluşabilir. 


\section{Sonuç ve Değerlendirme}

İnsan sağlığını tehdit eden Covid-19 salgını, kısa bir sürede dünya geneline yayılmış ve ülkeleri sadece sağlık alanında değil ekonomik anlamda da zora sokmuştur. Ülkeler aldıkları tedbirler ve uyguladıkları yasaklar ile hem halk sağlığını hem de ekonomilerini kurtarma çabası içerisindedirler. Covid -19 salgınından en fazla etkilenen sektörün hizmet sektörü ve alt bileşeninde turizm olduğunu söylemek yanlış olmayacaktır.

Turizm sektörünün Covid-19'dan iki farklı yolla etkileneceğini söyleyebiliriz. Bunlardan ilki seyahat sinırlaması ve karantinalar nedeniyle turizm faaliyetlerinin yapılamaması, ikincisi ise ekonomik açıdan müşkül duruma düşen bireylerin turizm faaliyetine katılamamasıdır. Her iki sebebinde turizm talebini düşüreceği aşikârdır. Türkiye'nin 2020'nin ilk 11 ayındaki toplam turist sayısı bir önceki seneye göre \%72 oranında azalmıştır. Turist sayısındaki azalmanın sadece ülkemize özgü değil dünya genelinde olması, ülkemize toparlanma aşamasında bazı firtsalar sunabilir. Bu durumu aşmanın ilk yolu iç turizm faaliyetlerini hareketlendirmektir. Bu aşamada yapılması gereken yerli turisti teşvik etmek için kampanyalar yapılması ve cazip firsatların sunulmasidir.

Covid-19 sonrası turistik tüketici davranışlarında bazı değişimler beklenmektedir. Yeni normal dönemde kitlesellikten uzak, doğa ile iç içe, katılımın az olduğu bireysel tatiller ön plana çıkmaktadır. Bu durum, Türkiye gibi kitle turizminin yoğun olarak yapıldığı ülkelerde bir dezavantaj olarak görülmektedir. Kitle turizmi, genellikle yaz aylarında yapılan, turistin konakladığı yer dışına hiç çıkmadığı, bölgedeki diğer turistik yerleri ziyaret etmediği, yerelden alışveriş yapmadığı dolayısıyla otel dışında hiçbir harcama yapmadığı bir tatil anlayışını kapsamaktadır. Ayrıca bu anlayış ile gelen turistin orta gelir ve altı olduğu aynı zamanda yerli turistten daha ucuza konakladığı yıllardır eleştirilmektedir (Kalkınma Bakanlığı, 2018: 47-48). Türkiye'nin dünya genelinde turist gelen ülkeler sıralamasında ilk on içerisinde yer alması ama turizm gelirleri listesinde ilk 10 da yer alamaması bu durumun bir işareti sayılabilir. Bu nedenlerden dolayı Türkiye turizm politikasında turizmi çeşitlendirme, alternatif turizm türlerini ortaya çıkarma ve turizmi dört mevsime yayma çabası içerisindedir. Covid-19 salgını sonrası bu durumun kendiliğinden buraya doğru evrilmesi bir firsat olarak değerlendirilebilir. Otel yöneticilerinin yeni normalde gerçekleşmesi beklenen yeni tatil anlayışına göre kendilerini şekillendirmeleri gerekmektedir. Nitekim yapılan çalışmalarda bazı otellerin bunun farkında olduğu ve buna yönelik içinde mutfak bulunan çok odalı süit odalar, villa tarzı bağımsız yapılar vb. bazı adımlar attığı görülmektedir.

Pandemi sonrası doğa temelli alternatif turizme doğru bir eğilim olmuştur. Tarım turizmi, kırsal turizm, dağ turizmi yayla turizmi ve eko turizm gibi alternatif turizm türlerini canlandıracak bu eğilim Türkiye için bir firsat niteliğindedir. Çünkü Türkiye coğrafi olarak geniş bir kırsal alana sahiptir. Kırsal alanların büyük çoğunluğu da kitle 
turizminin yoğun olarak gerçekleştiği Ege ve Akdeniz kıyılarında yer almaktadır. Bu durum aynı zamanda o bölgedeki tesisler için de avantajdır.

Yukarıdaki bilgiler 1şığında görülüyor ki Covid-19 hem kitsellikten uzaklaşıp alternatif turizm türlerine yönelme hem de turizmi dört mevsime yaymak konusunda büyük bir avantaj sunmaktadır. Bu durumun ülke ve işletmeler bazında çok iyi değerlendirilmesi ve buna yönelik turizm politikaları, tanıtım, reklam faaliyetleri ile desteklenmesi gerekmektedir. Böylelikle uzun vadede hem turist profilinde iyileşme hem de turizm gelirlerinde artış beklenebilir.

Covid-19 sonrası lehimize kullanabileceğimiz bir başka durum ise sağlık turizmidir. Salgın esnasında gelişmiş ülkeler ve Akdeniz çanağındaki turizme rakip ülkeler arasında; vaka, iyileşme, vefat sayılarından ve tedavi olanaklarından pandemi ile mücadeleyi en iyi yöneten ülke Türkiye olmuştur. Uluslararası basında da sık sık yer alan bu durum Türkiye'ye olan güveni arttırmıştır. Bu durum Türkiye'ye gelen yabancı turist sayısının arttırılması için bir firsattır. Aynı zamanda bundan sonra değişecek olan tatil anlayışında, sağlı hizmeti ile turizm hizmetini birleştirerek; medikal turizm, termal turizm, ileri yaş turizmi, bakıma muhtaç ve engelli turizmi gibi çeşitli ürünler sunmak Türkiye'nin turizmden elde edeceği geliri de arttıracaktır.

Bundan sonraki süreçte turistlerin temizlik ve hijyen konularında güveni ön planda tutacakları görülmektedir. Buna yönelik atılacak adımlar aynı zamanda kontrollü ve sağlıklı turizmi de destekleyecek, turizmin sürdürülebilirliğini arttıracaktır.

Sonuç olarak salgının etkilerini tamamen yok etmek mümkün değildir. Ancak uygulanacak bazı politikalarla en aza indirmeye çalışılabilir. Bu aşamada turizmde avantajlı olduğumuz alanlara yoğunlaşarak krizi fırsata çevirmeye çalışılmalıdır.

\section{Kaynakça}

Abu Bakar, N. ve S. Rosbi (2020). Effect of Coronavirus disease (COVID-19) to tourism industry. International Journal of Advanced Engineering Research and Science, Vol-7, Issue-4, 189-193.

Acar, Y. (2020). Yeni Koronavirüs (Covid-19) Salgını ve Turizm Faaliyetlerine Etkisi. Güncel Turizm Araştırmalarl Dergisi, 4(1), 7-21.

Akyol, C. (2020). Turizm Eğitimi Alan Öğrencilerin Covid-19 Salgınına Yönelik Görüşleri. Journal of Gastronomy, Hospitality and Travel (JOGHAT) 3(1), 112121.

Alaeddinoğlu, F. ve Rol, S. (2020). Covid-19 Pandemisi ve Turizm Üzerindeki Etkileri. Van Yüzüncü Yll Üniversitesi Sosyal Bilimler Enstitüsü Dergisi, Salgın Hastalıklar Özel Sayısı, 233-258 
Arslan E. ve Kendir H. (2020). COVID-19 Salgını Sonrası Yükselen Trend Kırsal Turizm: Zile Örneği. Türk Turizm Araştırmalarl Dergisi, 4(4): 3668-3683.

Atay, L. (2020). Covid-29 Salgını ve Turizme Etkileri. Seyahat ve Otel Işsletmeciliği Dergisi, 17(1).

Aydın, B. ve Doğan, M. (2020). Yeni Koronavirüs (COVİD-19) Pandemisinin Turistik Tüketici Davranışları ve Türkiye Turizmi Üzerindeki Etkilerinin Değerlendirilmesi. Pazarlama Teorisi ve Uygulamaları Dergisi, 6 (1), 93-115.

Bahar, O. ve Çelik İlal, N. (2020). The Economic Effects of Coronavirus (COVID-19) in the Tourism Industry. International Journal of Social Sciences and Education Research, 6(1), 125-139.

Çakır, P. ve. Barakazı M. (2020). Koranavirüs Sürecinin Turizm Sektörüne Etkisi ve Salgına Karşı Alınan Tedbirler, Anadolu üni. Sosyal bilimler dergisi, c:20, s:3, 313-332.

Çetin G., ve Göktepe, S. (2020). Covıd-19 Pandemisinin Turizm Endüstrisi Üzerindeki Etkileri, Editörler: D. Demirbaş, V. Bozkurt ve S. Yorgun, Covid-19 Pandemisinin Ekonomik, Toplumsal ve Siyasal Etkileri, İstanbul: İstanbul Üniversitesi Yayınları.

Çınar, F. ve Özkaya B. (2020). Koronavirüs (COVİD-19) Pandemisinin Medikal Turizm Faaliyetlerine Etkisi. Sağlık ve Sosyal Refah Araştırmaları Dergisi, Cilt 2, Sayı 2, 35-50.

Desbiolles, F. H. (2020) Socialising Tourism For Social and Ecological Justice After COVID-19, Tourism Geographies, 22:3, 610-623.

Düzgün, E. ve Kurt A. (2020). Covid-19 (Koronavirüs) Salgınının Turist Rehberleri Üzerindeki Etkileri: Ankara Turist Rehberleri Odası Örneği, KSBD, Sonbahar, Y. 12, S. 23: 18-38

Dwyer, L., Forsyth, P., Spurr, R. ve Van Ho, T. (2006). Economic Effects of the World Tourism Crisis on Australia. Tourism Economics, 12(2), 171-186.

Eugenio-Martin, J. L. ve Campos-Soria, J. A. (2014). Economic Crisis and Tourism Expenditure Cutback Decision. Annals of Tourism Research, 4, 53-73.

Gössling, S., Scott D. ve Hall, M. C. (2020). Pandemics, Tourism and Global Change: A Rapid Assessment of COVID-19. Journal of Sustainable Tourism. Erişim: https://doi.org/10.1080/09669582.2020.1758708

Hale, T., Petherick, A., Phillips, T. ve Webster, S. (2020). Variation in Government Responses to COVID-19. Blavatnik school of government working paper, 31 . 
Işı1k Erol, S. (2020). Covid-19'un Turizm Sektöründe İstihdama Etkisi: İtalya, İspanya ve Türkiye Örnekleri, İşletme ve İktisat Çalışmaları Dergisi Y11: 2020, Cilt: 8, Sayı: 2, s.38-49.

Kalkınma Bakanlığı (2018), On Birinci Kalkınma Planı (2019-2023), Turizm Özel İhtisas Komisyonu Raporu, Ankara.

Kabadayı, M. ve Kardeş, N. (2020). Kovid-19'un (Koronavirüsün) Yerli Turist Davranışı ve Seyahat Eğilimlerine Etkileri, Türk Turizm Araştırmaları Dergisi, 4(4): 3703-3719.

Karadeniz, E, Beyaz F.S., Ünlübulduk, S. ve Kayhan L.E. (2020). Covid-19 Salgınının Turizm Sektörüne Etkilerinin ve Uygulanan Stratejilerin Değerlendirilmesi: Otel Yöneticileri Üzerinde Bir Araştırma, Türk Turizm Araştırmaları Dergisi, 4(4): 3116-3136.

Kiper, V. O., Saraç, Ö., Çolak, O. ve Batman, O. (2020). Covid-19 Salgınıyla Oluşan Krizlerin Turizm Faaliyetleri Üzerindeki Etkilerinin Turizm Akademisyenleri Tarafından Değerlendirilmesi. Balıkesir Üniversitesi Sosyal Bilimler Enstitüsü Dergisi, 23(43), 527-551.

İbiş, S. (2020). Covid-19 Salgınının Seyahat Acenteleri Üzerine Etkisi. Safran Kültür ve Turizm Araştırmaları Dergisi, 3(1): 85-98.

Korkut, Y., Eken M., Zeren. F., ve Altunışık R. (2020). Covid- 19 Pandemisinin Turizm Üzerindeki Etkileri: Borsa İstanbul Turizm Endeksi Üzerine Bir İnceleme, Gaziantep Üni. Journal Of Social Sciences, 71-86.

Küçükaltan, D., Tükeltürk, Ş. A. ve Çiftçi, G. (2015). Otel Işsletmelerinde Kriz Yönetimi. Ankara: Detay Yayıncılık.

Lee, C. C. ve Chen, C. J. (2011). The Reaction of Elderly Asian Tourists to Avian Influenza and SARS. Tourism Management, 32(6), 1421-1422.

Mahase, E. (2020). Coronavirus: Global Stocks of Protective Gear Aredepleted, with Demand at "100 times" Normal Level, WHO Warns. BMJ 2020;368:m543 doi: 10.1136/bmj.m543 (Published $10 \quad$ February 2020). https://www.bmj.com/content/bmj/368/bmj.m543.full.pdf.

Oran, İ. B. (2020). Covid-19'un Uluslararası Turizm Üzerinde Diğer Krizlerden Farklı Etkileri. Turkish Studies, 15(4), 807-826.

Özaltın Türker, G. (2020). Covid-19 Salgını Turizm Sektörünü Nasıl Etkiler? Turizm Akademisyenleri Perspektifinden Bir Değerlendirme. International Journal of Social Sciences and Education Research, 6(2), 207-224. 
Özcan,.ve Kar M. (2020). Büyük Tecrit Sonrası Turizm Sektörünün Geleceği, Editörler: Şeker, M. Özer A. ve Korkut C., Küresel Salgının Anatomisi İnsan ve Toplumun Geleceği, Ankara: Türkiye Bilimler Akademisi.

Özçoban, E. (2020), Koronavirüs'ün (Covid-19) Turizm Sektörü Üzerindeki Etkileri ve Türkiye'nin Kirsal Turizm Potansiyeli Üzerine Bir Analiz, Turkish Studies, 15(4), 853-867.

Özdemir- Altınay, M. (2020). Covıd-19 Salgını Sonrası Alınan Önlemlerle Turizm: Muhtemel Senaryolar. Journal of Recreation and Tourism Research, 7 (2), 222238.

Öztaş, K ve T. Karabulut (2006). Turizm Ekonomisi Genel Turizm Bilgileri, Ankara: Nobel Yayıncilik.

Page, S.J. and Getz, D. (1997). The Business of Rural Tourism: International Perspectives. UK: International Thomson Business Press.

Papatheodorou, A., Rosselló, J., ve Xiao, H. (2010). Global Economic Crisis and Tourism: Consequences and Perspectives. Journal of Travel Research, 49(1), 3945 .

Skare, M., Soriano, D. R., \& Porada-Rochon', M. (2021). Impact of COVID-19 on the travel and tourism industry. Technological Forecasting and Social Change, 163, 120469.

T.C. Sağlık Bakanlığı. (2020, 02 25). Covid 19 (2019-n CoV Hastalığı) Rehberi (Bilim Kurulu Çalışması). T.C. Sağlık Bakanlığı Halk Sağlığı Genel Müdürlüğü

Tang, T. C. ve Wong, K. N. (2009). The SARS Epidemic and International Visitor Arrivals to Cambodia: Is the Impact Permanent or Transitory? Tourism Economics, 15(4), 883-890.

T.C. Kültür ve Turizm Bakanlığı (2020). Sınır Bülteni, Kasım 2020.

Torales, J., O’Higgins, M., Castaldelli-Maia, J. M. ve Ventriglio, A. (2020). The outbreak of COVID-19 Corona Virus and its Impact On Global Mental Health. International Journal of Social Psychiatry.

TURSAB (2020). Son Verilerle Türkiye Turizm Ístatistikleri Raporu, Kasım 2020, Sayı:2.

Tse, T. S. (2006). Crisis Management in Tourism. Editörler: D. Buhalis, \& C. Costa, Tourism Management Dynamics (s. 28-38). Elsevier Butterworth-Heinemann.

Wen, J., Kozak, M., Yang, S. ve Liu, F. (2020). Covid-19: Potential Effects on Chinese Citizens Lifestyle and Travel. Tourism Revie. 
WHO. (2020). Coronavirus Disease (2019). (COVID-19) Situation Report - 52. https://www.who.int/docs/default-source/coronaviruse/situationreports/20200312-sitrep52-Covid-19.pdf?sfvrsn=e2bfc9c0_4 .

Yenişehirlioğlu, E. ve Sahla H. (2020). Covid 19 Pandemisinin Türkiye İç Turizmine Yansımaları: Değişen Talep Üzerine Bir Araştırma. İstanbul Ticaret Üniversitesi Sosyal Bilimler Dergisi, Covid-19 Sosyal Bilimler Özel Sayıs1 Y11:19 Say1:37, 355-368.

Yazıcı Ayyıldız, A. (2020). Covid-19 Salgın Döneminde Otellerin Pazarlama Stratejileri: Kuşadası Örneği. BMIJ, (2020), 8(3): 3328-3358.

Zheng, Y., Goh, E. ve Wen, J. (2020). The Effects of Misleading Media Reports About COVID-19 on Chinese Tourists' Mental Health: a Perspective Article. Anatolia, 31(2), 337-340. 